\title{
Algoritma Backpropagation Prediksi Harga Komoditi terhadap Karakteristik Konsumen Produk Kopi Lokal Nasional
}

\author{
Petti Indrayati Sijabat ${ }^{1}$, Yuhandri ${ }^{2}$, Gunadi Widi Nurcahyo ${ }^{3}$, Anita Sindar ${ }^{4}$ \\ ${ }^{1,2,3}$ Program Studi Teknik Informatika, Universitas Putra Indonesia "YPTK" Padang \\ ${ }^{4}$ Program Studi Teknik Informatika STMIK Pelita Nusantara \\ 1,2,3 Jl. Raya Lubuk Begalung, Sumatera Barat \\ ${ }^{4} \mathrm{Jl}$. Iskandar Muda No. 1 Medan \\ e-mail: ${ }^{1}$ petti.jabat@gmail.com, ${ }^{2}$ yuhandri.yunus@ gmail.com, ${ }^{3}$ gunadiwidi@yahoo.co.id, \\ 4haito_ita@yahoo.com
}

\begin{abstract}
Abstrak
Kopi bagian penting dari komoditi pasar nasional maupun internasional. Secara nasional jenis kopi lokal beragam sesuai nama daerah penghasil mengalami naik turun harga Perlu perencanaan teknologi untuk mengetahui harga kopi ke depan. Peramalan atau prediksi dalam ilmu komputer berkaitan dengan perkiraan berkala produksi, penawaran dan permintaan pada masa tertentu menggunakan alat ukur yang akurat dan teruji. Metode Backpropagation digunakan untuk prediksi harga. Proses algoritma backpropagation antara lain input data, melakukan tahap normalisasi /transformasi data, iterasi, pelatihan dan menentukan parameter jaringan, kalkulasi error, mendapatkan hasil prediksi. Perancangan arsitektur JST, dilakukan penentuan jumlah layer pada lapisan input, lapisan tersembunyi dan lapisan output. Penelitian ini menggunakan Matlab R2013a dengan metode Backpropagation. Pengambilan input, penelusuran error dan penyesuaian bobot berguna untuk menghasilkan nilai prediksi harga kopi. Hasil prediksi harga kopi dari harga aktual 74205 ke hasil harga prediksi 73668 dengan akurasi 99.9928, harga aktual 73892 ke harga prediksi 73175 dengan akurasi 99.9903, harga aktual 77981 ke hasil prediksi 77481 akurasi 99.9936.
\end{abstract}

Kata Kunci: Syaraf Tiruan, Prediksi, Harga Kopi, Backpropagation

\begin{abstract}
Coffee is an important part of the national and international market commodity. Nationally, the types of local coffee vary according to the name of the producing region experiencing ups and downs in price. It needs technology planning to find out the price of coffee going forward. Forecasting or prediction in computer science is related to periodic estimates of production, supply and demand at certain times using accurate and tested measuring tools. Backpropagation method is used for price prediction. The backpropagation algorithm process includes inputting data, performing the normalization / transformation of data, iterating, training and determining network parameters, calculating errors, getting predictive results. The design of the ANN architecture determines the number of layers in the input layer, the hidden layer and the output layer. This research uses Matlab R2013a. Taking input, tracking errors and adjusting weights are useful for producing predictive value of coffee prices. Coffee prediction results from actual prices 74205 to the predicted price of 73668 with an accuracy of 99.9928, the actual price of 73892 to the predicted price of 73175 with an accuracy of 99.9903 , the actual price of 77981 to the predicted result of 77481 with an accuracy of 99.9936.
\end{abstract}

Keywords: Neural Networks, Predictions, Coffee Prices, Backpropagation

eISSN: 2477-3255, pISSN: 2086-4884 https://doi.org/10.31849/digitalzone.v11i1.3880 


\section{Pendahuluan}

Perdagangan ekspor kopi memberikan devisa dan berdampak menaikkan kesejahteraan para petani dilihat dari statistik Tahun 2015 (Ditjend Perkebunan, 2016). Menurut Tri (2015) pengelolaan komoditas kopi telah membuka peluang bagi lima juta petani, serta bagi pedagang pengumpul hingga eksportir, buruh perkebunan besar dan buruh industri pengolahan kopi. Permintaaan pasar yang naik turun dan kualitas produksi kopi yang belum maksimal mengakibatkan harga kopi tidak stabil. Informasi harga kopi dapat diperoleh melalui berita resmi dari lembaga nasional seperti BAPPEBTI (Badan Pengawas Perdagangan Berjangka Komoditi). Jaringan Syaraf Tiruan merupakan metode yang mampu melakukan proses matematis untuk prediksi kertersediaan komoditi pangan. Menurut Haykin (2009) Jaringan Saraf Tiruan (JST) atau Artificial Neural Network (ANN) adalah sebuah jaringan yang dirancang untuk menyerupai otak manusia yang bertujuan untuk melaksanakan suatu tugas tertentu. Jaringan ini biasanya diimplementasikan dengan menggunakan komponen elektronik atau disimulasikan pada aplikasi komputer [1].

Pada algoritma Backpropagation, dilakukan proses pengolahan data terdahulu yang dijadikan input untuk prediksi ketersediaan komoditi pangan. Willian J. Stevenson (2009:72) mendefinisikan peramalan sebagai input dasar dalam proses pengambilan keputusan manajemen operasi dalam memberikan informasi tentang permintaan di masa mendatang dengan tujuan untuk menentukan berapa kapasitas atau persediaan yang akan dibutuhkan untuk memenuhi permintaan. Seperti, kapasitas yang diperlukan untuk membuat keputusan staffing, budget yang harus disiapkan, pemesanan barang dari supplier, dan partner dari rantai pasok yang dibutuhkan dalam membuat suatu perencanaan. Menurut Marshall dan Oliver (1995), peramalan adalah sesuatu yang harus dilakukan jika ingin merencanakan untuk masa depan, menggunakan data masa lalu untuk mengidentifikasi trend jangka pendek, menengah ataupun panjang dan menggunakan pola-pola ini untuk memproyeksikan posisi sekarang untuk masa yang akan datang [2].

Prediksi adalah masalah sulit dan dapat dilihat sebagai pengenalan pola sementara yang sangat cocok diselesaikan dengan JST. Subjek variable perdiksi dapat berbeda dari data sebelumnya (independent variables). Metode backpropagation dan fungsi aktivasi sigmoid adalah hal yang paling penting dan merupakan metode yang digunakan untuk pelatihan multilayer neural networks feedfoward. Tumbuhan kopi (Coffea Sp.) tanaman berbentuk pohon mencapai tinggi $12 \mathrm{~m}$ bila dibiarkan tumbuh sendiri. Jenis kopi dikenal dari bijinya yaitu kopi Arabika dan Robusta. Konsumsi minuman kopi diproses dari biji kopi arabika. 70\% persen kopi yang dijual di merupakan jenis kopi arabika. Kopi ini banyak tumbuh di Afrika bagian timur dan tengah, Amerika Selatan, serta Benua Asia bagian selatan dan tenggara. Penelitian ramalan jumlah impor kopi dari Sumatera Utara menurut negara asal mengimplementasikan algoritma Backpropagation menghasilkan kenaikan jumlah impor dalam negeri, pemerintah mesti melakukan kegiatan ekonomi internasional secara legal. Permasalahan kenaikan jumlah impor tiap tahunnya yang terjadi diteliti oleh peneliti untuk memprediksi total import kopi selama lima tahun berikutnya menggunakan 5 model arsitektur [3]. Metode Backpropagation dapat digunakan untuk mempelajari pola tingkat kesembuhan penyakit Demam Berdarah Dengue (DBD) di kota Ambon. Dari 82 data yang digunakan, 62 data digunakan untuk pelatihan sementara 20 data dipakai sebagai data testing [4]. Data yang dipakai adalah data Demam Berdarah Dengue (DBD) periode 2011-2015 di kota Ambon. Hasil penelitian memperoleh akurasi sebesar $90 \%$, arsitektur jaringan terbaik dari satu hidden layer dengan jumlah neuron sebanyak 25 neuron dan algoritma pelatihan terbaik yaitu dengan menggunakan learning rate sebesar 0,4 dengan MSE 0,0099 [5].

Algoritma Backpropagation memperoleh akurasi 97,92\% untuk memprediksi harga komoditi pangan di Kota Palu. Data yang digunakan bersumber dari Dinas Pertanian Provinsi 
Sulawesi Tengah. Dalam laporan penelitian ini diprediksi fluktuasi harga kebutuhan pokok pada tahun 2016 berdasarkan data tahun 2015. Prediksi fluktuasi dibuat per bulan dimana rentang waktu januari-maret diperoleh akurasi sebesar 97,41\%, sedangkan periode januari-desember diperoleh akurasi 97,92\% [6]. Backpropagation mendapatkan akurasi sebesar 91,72\% pada kasus klasifikasi suara jantung. Penelitian ini menggunakan input data berupa file suara jantung berformat .MP3 dari web, masing-masing file berbeda ukuran dan durasi suaranya. Dari data file suara jantung tersebut, metode Backpropagation terbukti mampu mengklasifikasi dengan baik kondisi jantung normal dan abnormal [7]. Pada penelitian tentang analisa perbandingan kemungkinan probabilitas dalam memperkirakan pergerakan harga saham bertujuan untuk mengetahui pengaruh rasio probabilitas terhadap harga saham. Penelitian yang telah dilakukan untuk memprediksi harga emas menggunakan model AR dan ARCH bagian dari metode time series dan data digunakan adalah data harga emas yang diperoleh dari website historis harian antam dari tahun 2007-2017 [8]. Penelitian tahun 2018 melakukan prediksi kelulusan mahasiswa agar mampu memperhitungkan waktu lama kelulusan mahasiswa menggunakan algoritma Backpropagation. Bentuk implementasi telah diteliti untuk memprediksi ketidaktepatan waktu kelulusan mahasiswa berakibat angka kelulusan tepat waktu cenderung rendah setiap tahunnya menghasilkan persentase akurasi prediksi sebesar $98.97 \%$ dan peneliti menggunakan sebanyak 318 sampel data yang $70 \%$ data digunakan sebagai data acuan dan $30 \%$ data digunakan sebagai data olahan input [9].

Dalam penelitian ini penerapan metode Backpropagation menghasilkan perhitungan peramalan kopi dari pemetaan konsumen kopi. Tahapan implementasi metode Backpropagation memberikan hasil akurasi yang diperoleh dari perhitungan error MSE. Arsitektur Jaringan Saraf Tiruan (JST) yang dipergunakan mempengaruhi hasil prediksi harga kopi. Tahap pelatihan terhadap data yang telah dinormalisasi dan ditentukan arsitekturnya, pelatihan dilakukan pertama untuk algoritma Backpropagation standar, setelah itu baru dilakukan kembali pelatihan dengan menambahkan learning rate dan kooefisien momentum pada update bobot dengan tujuan pelatihan untuk membandingkan nilai epoch dan penentuan nilai Mean Square Error untuk mengetahui tingkat validasi hasil.

Pengujian sistem dilakukan dengan bobot sembarang mentukan error untuk data training secara keseluruhan. Data error training masih lebih besar dari toleransi yakni 0,01. Training data pertama, masukkan bobot baru. Karena memiliki sebuah keluaran maka, Hitung penjumlahan kesalahan dari unit tersembunyi. Hitung semua perubahan Bobot Perubahan bobot unit keluaran. Tujuan yang ingin dicapai dalam penelitian adalah mengimplemetasikan algoritma Backpropagation dalam memprediksi harga kopi Arabika dan Robusta, dan untuk membangun dan merancang hasil prediksi harga komoditi pada produk kopi Arabika dan Robusta lokal nasional dengan algoritma Backpropagation diaplikasikan pada software Matlab R2013a. Penelitian ini bermanfaat untuk untuk memudahkan para penjual kopi (khususnya penjual) dalam memprediksi harga komoditi kopi dan mendapatkan hasil pemetaan konsumen kopi dalam produk kopi lokal nasional dan membantu dalam menghasilkan prediksi harga kopi dan dapat menggali informasi lebih lanjut tentang harga kopi untuk kedepannya dalam produk kopi lokal.

\section{Metode Penelitian}

Penelitian Indri Sriwahyuni Purba dan Anjar Wanto, (2018) memprediksi jumlah nilai impor dengan algoritma Backpropagation melewati 2 proses yakni proses pelatihan (training) dan proses pengujian (testing), hasil dari masukan yang diberikan oleh lapisan input. Pada penelitian ini menghasilkan model arsitektur terbaik dan keakurasian 100\% dari 5 model arsitektur dengan epoch yang terjadi 2807 dalam waktu 17 detik [10]. Bagan alir analisa 
perancangan ini dibuat dengan tujuan untuk memudahkan tahapan analisa dan perancangan sistem. Memprediksi harga komoditi dimaksud dengan objek kopi nasional berupa kopi Arabika dan kopi Robusta. Memprediksi terhadap pemetaan karakteristik konsumen didefinisikan sebagai harga kopi nasional yang sudah ditetapkan pada batasan masalah. Pada penelitian ini, bagan alir analisa dan perancangan sistem untuk memprediksi harga kopi terhadap pemetaan karakteristik konsumen pada produk lokal nasional ditunjukkan pada Gambar 1.

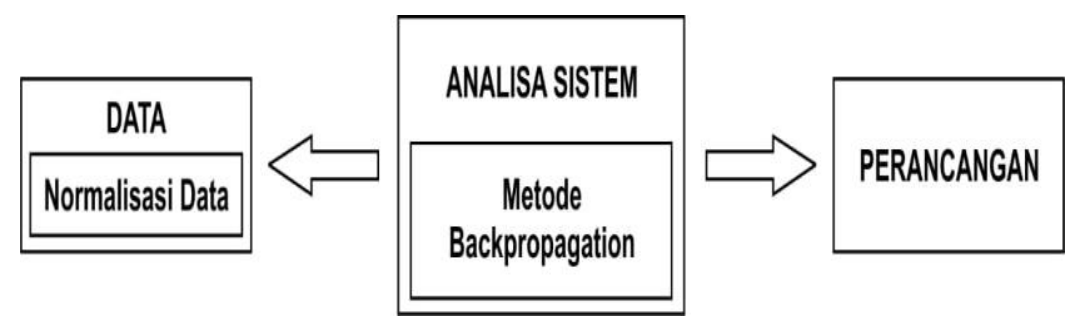

Tahapan metode penelitian:

Gambar 1. Tahapan Penelitian

A. Normalisasi Data

Dalam pengolahan Data yang digunakan ada data latih, data uji dan data real. Data latih adalah data yang akan diinputkan pada saat melakukan pengujian yaitu data Kopi dari tahun 2015 sampai 2019. Data Uji terdapat data Lapisan masukan yang terkait didalamnya adalah inputan masukan dari Nopember dan inputan keluaran adalah Desember tahun 2019. Analisanya adalah data yang akan di uji berdasarkan data masa lampau (pengalaman) dan untuk faktor mempengaruhinya hanya selisih dari harga bulan sebelumnya [11]. Selisih dari harga sebelumnya akan dijadikan target dalam mendapatkan hasil prediksi, sebagai contoh adalah dari Januari akan dijadikan sebagai input masukan dan untuk Februari sebagai inputan keluaran. Data real adalah data nyata, data target, data yang akan diprediksi harga berdasarkan hasil kerja jaringan. Data real dan hasil data prediksi akan dipetakan berdasarkan provinsi masing-masing. Hasil prediksi terdapat hasil akurasi dan MSE dan rata-rata hasil akurasi tertinggi [12]. Adapun data dengan jenis data sekunder yaitu data Dinas Perindustrian kota Medan yang menyatakan bahwa konsumsi kopi nasional mencapai sekitar 250 ribu ton tumbuh 10,54\% menjadi 276 ribu ton.

B. Analisa Sistem (Algoritma Backpropagation)

Proses algoritma Backpropagation dilakukan dengan mendefinisikan nilai awal untuk variabelvariabel yang diperlukan seperti menentukan nilai input, nilai output, nilai bobot, nilai bias, learning rate $(\alpha)$ dan nilai batas ambang/threashold ( $\Theta$ ) [13]. Tahapan algoritma Backpropagation:

1. Input Data

2. Melakukan tahap Normalisasi / Transformasi Data

3. Melakukan Iterasi

4. Melakukan Pelatihan dan Menentukan Parameter Jaringan

5. Menentukan Kalkulasi error

6. Melakukan Proses Pengujian algoritma Backpropagation

7. Proses Mendapatkan Hasil

8. Hasil Prediksi

Proses algoritma Backpropagation memiliki Arsitektur Jaringan Saraf Tiruan (JST) sangat mempengaruhi tingkat akurasi hasil prediksi, sehingga pemilihan arsitektur JST yang tepat menjadi hal yang harus dilakukan [14]. Perancangan arsitektur JST, hal yang harus dilakukan adalah menentukan jumlah layer pada lapisan input, layer tersembunyi dan lapisan output [15]. 
Pada penelitian ini arsitektur JST yang digunakan untuk memprediksi harga komoditas kopi Arabika dan Robusta di tahun 2019:

1. Lapisan Masukan (input layer) $=10$ layer.

2. Lapisan tersembunyi (hidden layer) $=\mathrm{n}$ layer (ditentukan oleh pengguna dan dapat disesuaikan untuk memperoleh akurasi terbaik).

3. Lapisan keluaran (output layer) $=10$ lapisan $(2 \times 5)$

4. Lapisan keluaran 2 untuk Jenis Kopi (Kopi Arabika dan Robusta)

C. Perancangan

Pada permasalahan ini arsitektur Jaringan Syaraf Tiruan yang digunakan adalah Jaringan Syaraf Tiruan dengan banyak layer (multilayer net) dengan algoritma Backpropagation, yang terdiri dari:

a. Layer masukan (input) dengan $10 \operatorname{simpul}\left(x_{1}, x_{2}, x_{3}, x_{n}\right)$.

b. Layer tersembunyi (Hidden) dengan jumlah simpul ditentukan oleh pengguna $\left(y_{1}\right.$, $\left.y_{2} \ldots y_{n}\right)$.

c. Layer keluaran (Output) dengan 10 simpul (z).

Penerapan Jaringan Syaraf Tiruan dalam langkah prediksi kopi yang akan dibangun menggunakan algoritma propagasi balik (Backpropagation). Fungsi aktivasi Sigmoid digunakan untuk proses perhitungan pada nilai aktual output dengan hidden layer dan nilai aktual output luaran layer.

\section{Hasil dan Pembahasan}

Pengolahan data Jaringan Syaraf Tiruan dimulai dengan menentukan data masukan serta target luaran data. Data yang digunakan adalah data tahun 2015-2019 dengan pengujian data kopi Arabika dan Robusta di tahun 2019. Dari data harga kopi yang telah dijabarkan dilakukan proses pendefinisian data masing-masing provinsi untuk harga kopi Arabika tahun 2015-2019 dan kopi Robusta tahun 2015-2019. Data yang akan diolah pada Tabel 1 dan Tabel 2.

Tabel 1. Harga Kopi Arabika Pada Tahun 2015-2019

\begin{tabular}{|c|l|c|c|c|c|c|}
\hline \multirow{2}{*}{ No } & \multicolumn{2}{|c|}{ Provinsi } & \multicolumn{5}{c|}{ Harga/Kg Tahun } \\
\cline { 3 - 7 } & & 2015 & 2016 & 2017 & 2018 & 2019 \\
\hline 1 & Sumatera Utara & 45188 & 44687 & 64262 & 68819 & 70721 \\
\hline 2 & Aceh & 45361 & 45514 & 66007 & 70052 & 70054 \\
\hline 3 & Sulawesi Selatan & 47813 & 47785 & 72199 & 72924 & 76551 \\
\hline 4 & Sumatera Barat & 45213 & 43460 & 64434 & 70138 & 69199 \\
\hline 5 & Nusa Tenggara Timur & 44584 & 47228 & 68207 & 68748 & 73550 \\
\hline
\end{tabular}

Tabel 2. Harga Kopi Robusta Pada tahun 2015-2019

\begin{tabular}{|c|l|c|c|c|c|c|}
\hline No & \multicolumn{2}{|c|}{ Provinsi } & \multicolumn{5}{c|}{ Harga/Kg Tahun } \\
\hline & & 2015 & 2016 & 2017 & 2018 & 2019 \\
\hline 1 & Sumatera Utara & 44437 & 44786 & 64981 & 69603 & 70748 \\
\hline 2 & Aceh & 45285 & 44094 & 64195 & 70278 & 69851 \\
\hline 3 & Sulawesi Selatan & 52901 & 47785 & 67843 & 71230 & 79979 \\
\hline 4 & Sumatera Barat & 45068 & 44451 & 66423 & 71196 & 71235 \\
\hline 5 & Nusa Tenggara Timur & 44819 & 47742 & 67137 & 70089 & 69769 \\
\hline
\end{tabular}

Dari data input dan data target yang sudah disajikan akan dilakukan proses normalisasi dengan persamaan $\mathrm{Xn}=0.8(\mathrm{x}-\mathrm{a}) /(\mathrm{b}-\mathrm{a})+0.1$ dengan keterangan, $\mathrm{Xn}=$ Normalisasi, $\mathrm{x}=$ data yang mau dinormalisasi, $\mathrm{a}=$ nilai terkecil dari data input, $\mathrm{b}=$ nilai terbesar dari data input. Dengan 
memanfaatkan rumus normalisasi, data yang mau dinormalisasi maka terbentuk tabel hasil normalisasi data target harga kopi Arabika dari tahun 2015 sampai 2019 yang akan diinput.

Tabel 3. Hasil Normalisasi Data Target Harga Kopi Dari Tahun 2015 Sampai 2019

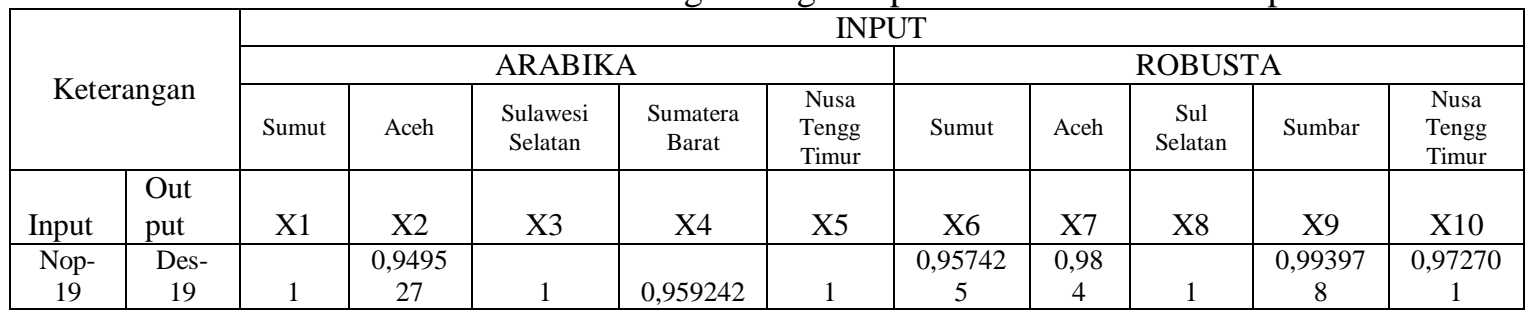

Tabel 4. Output Data Kopi

\begin{tabular}{|c|c|c|c|c|c|c|c|c|c|}
\hline Sumut & Aceh & $\begin{array}{c}\text { Sulawesi } \\
\text { Selatan }\end{array}$ & $\begin{array}{c}\text { Sumatera } \\
\text { Barat }\end{array}$ & $\begin{array}{c}\text { Nusa } \\
\text { Tenggara } \\
\text { Timur }\end{array}$ & Sumut & Aceh & $\begin{array}{c}\text { Sulawesi } \\
\text { Selatan }\end{array}$ & $\begin{array}{c}\text { Sumatera } \\
\text { Barat }\end{array}$ & $\begin{array}{c}\text { Nusa } \\
\text { Tenggara } \\
\text { Timur }\end{array}$ \\
\hline Y1 & Y2 & Y3 & Y4 & Y5 & Y6 & Y7 & Y8 & Y9 & Y10 \\
\hline 1 & 0,977105 & 1 & 0,970107 & 1 & 0,956934 & 0,985836 & 1 & 0,996555 & 1 \\
\hline
\end{tabular}

Tabel 5. Input Data Kopi

\begin{tabular}{|c|c|c|c|c|c|c|c|c|c|c|c|}
\hline \multicolumn{12}{|c|}{ INPUT } \\
\hline \multicolumn{7}{|c|}{ ARABIKA } & \multicolumn{5}{|c|}{ ROBUSTA } \\
\hline \multicolumn{2}{|c|}{ Keterangan } & \multirow{2}{*}{$\begin{array}{c}\text { Sumut } \\
\mathrm{X} 1\end{array}$} & \multirow{2}{*}{$\begin{array}{l}\text { Aceh } \\
\mathrm{X} 2\end{array}$} & \multirow{2}{*}{$\begin{array}{c}\begin{array}{c}\text { Sulawesi } \\
\text { Selatan }\end{array} \\
\text { X3 }\end{array}$} & \multirow{2}{*}{$\begin{array}{c}\begin{array}{c}\text { Sumatera } \\
\text { Barat }\end{array} \\
\mathrm{X} 4\end{array}$} & \multirow{2}{*}{$\begin{array}{c}\begin{array}{c}\text { Nusa } \\
\text { Tenggara } \\
\text { Timur }\end{array} \\
\text { X5 }\end{array}$} & \multirow{2}{*}{$\begin{array}{c}\text { Sumut } \\
\mathrm{X} 6 \\
\end{array}$} & \multirow{2}{*}{$\begin{array}{l}\text { Aceh } \\
\mathrm{X} 7 \\
\end{array}$} & \multirow{2}{*}{$\begin{array}{c}\begin{array}{c}\text { Sulawesi } \\
\text { Selatan }\end{array} \\
\mathrm{X} 8\end{array}$} & \multirow{2}{*}{$\begin{array}{c}\begin{array}{c}\text { Sumatera } \\
\text { Barat }\end{array} \\
\text { X9 }\end{array}$} & \multirow{2}{*}{$\begin{array}{c}\begin{array}{c}\text { Nusa } \\
\text { Tenggara } \\
\text { Timur }\end{array} \\
\mathrm{X} 10\end{array}$} \\
\hline Input & Output & & & & & & & & & & \\
\hline Jan-15 & Feb-15 & 41239 & $\begin{array}{c}4103 \\
8\end{array}$ & 46014 & 41426 & 41144 & 40018 & $\begin{array}{c}4032 \\
6\end{array}$ & 50987 & 41668 & 41509 \\
\hline Mar-15 & Apr-15 & 42954 & $\begin{array}{c}4205 \\
9\end{array}$ & 47157 & 42547 & 42671 & 40856 & $\begin{array}{c}4128 \\
2\end{array}$ & 51318 & 42007 & 43281 \\
\hline Apr-15 & Mei-15 & 43996 & $\begin{array}{c}4368 \\
4\end{array}$ & 47187 & 43080 & 43191 & 41315 & $\begin{array}{c}4460 \\
6\end{array}$ & 51410 & 44370 & 43722 \\
\hline Mei-15 & Jun-15 & 44523 & $\begin{array}{c}4452 \\
6\end{array}$ & 47271 & 43804 & 43161 & 42468 & $\begin{array}{c}4464 \\
2\end{array}$ & 52225 & 44852 & 43806 \\
\hline Jul-15 & Agst-15 & 44974 & $\begin{array}{c}4619 \\
4\end{array}$ & 47957 & 45070 & 44029 & 44223 & $\begin{array}{c}4551 \\
3\end{array}$ & 53375 & 45513 & 44448 \\
\hline $\begin{array}{r}\text { Agust- } \\
15\end{array}$ & Sep-15 & 46358 & $\begin{array}{c}4657 \\
6\end{array}$ & 48124 & 45917 & 42996 & 46890 & $\begin{array}{c}4573 \\
0\end{array}$ & 53900 & 46358 & 44678 \\
\hline Sep-15 & Okt-15 & 46508 & $\begin{array}{c}4691 \\
7\end{array}$ & 48603 & 47528 & 40527 & 48152 & $\begin{array}{c}4848 \\
2\end{array}$ & 54063 & 46405 & 45377 \\
\hline Okt-15 & Nop-15 & 47090 & $\begin{array}{c}4820 \\
9\end{array}$ & 48766 & 48608 & 47078 & 48361 & $\begin{array}{c}4878 \\
7\end{array}$ & 54141 & 46933 & 47455 \\
\hline Nop-15 & Des-15 & 48493 & $\begin{array}{c}4857 \\
8\end{array}$ & 49047 & 48886 & 48633 & 48711 & $\begin{array}{c}4909 \\
3\end{array}$ & 54319 & 47126 & 47964 \\
\hline Des-15 & Jan-16 & 49031 & $\begin{array}{c}4981 \\
2\end{array}$ & 49547 & 49713 & 46770 & 48952 & $\begin{array}{c}4936 \\
4\end{array}$ & 54765 & 48392 & 48635 \\
\hline Apr-16 & Mei-16 & 41890 & $\begin{array}{c}4257 \\
7 \\
\end{array}$ & 46520 & 41018 & 46139 & 43377 & $\begin{array}{c}4460 \\
6 \\
\end{array}$ & 51410 & 42739 & 47989 \\
\hline
\end{tabular}


Langkah-langkah Iterasi data algoritma Backpropagation menggunakan satu lapisan tersembunyi, kontinyu dan tidak menurun secara monoton :

a. Menentukan nialai awal, tahap mendefinisikan variabel-variabel.

b. Melakukan perhitungan dari nilai awal, tahap ini memiliki 2 langkah yaitu pada hidden layer dilakukan proses perhitungan actual output nya dan pada output layer dilakukan juga proses perhitungan actual outputnya.

c. Menghitung nilai error, pada tahap ini memiliki 2 langkah yaitu pada output layer dilakukan proses perhitungan error gradiaent nya, dan pada hidden layer dilakukan proses perhitungan error gradient.

d. Melakukan iterasi, merupakan tahap dalam pengujian dimana iterasi akan terus di lakukan jika error yang diharapkan belum tercapai.

Pada tahap inisialisasi awal, ada dua metode yang dapat dilakukan yaitu : pemberian nilai secara acak; inisialisasi bobot metode Nguyen-Widrow. Tahapan inisialisasi awal dengan memberikan nilai acak yang relatif kecil sebagai bobot awal pada JST. Nilai diberikan random tanpa menggunakan faktor skala nilai bobot metode Nguyen-Widrow.

Perancangan JST metode Backpropagation untuk memprediksi harga kopi di mulai dengan mempersiapkan data dengan 10 input dan 10 target. Pada perancangan manual ini diambil satu sampel data saja yaitu data harga kopi pada tiap-tiap tahun dalam rentang waktu 2015 hingga 2018. Data input 10 yang digunakan dan target yang ditentukan berlaku untuk pengolahan data kopi Arabika dan Robusta pada tahun 2015 sampai tahun 2019. 10 input data yang dimaksud adalah 10 data input untuk kopi Arabika dan 5 data input untuk data kopi Robusta dengan tahun yang sama dengan pengolahan data per bulan. Data yang akan diolah terdapat pada tabel harga Kopi yang telah dipaparkan. Data yang ada telah disederhanakan. Setelah dilakukan penyederhanaan data yang diolah dalam pelatihan JST, tahap selanjutnya adalah inisialisasi bobot awal. Masukan (input) yang diberikan adalah data harga kopi 2019 maka diperlukan nilai menghubungkan layer input ke layer tersembunyi, layer tersembunyi ke layer luaran terhubung dengan bobot, nilai bias dari input ke hidden, dari hidden ke output, dengan catatan bahwa bobot tersimpan secara acak yang nilai relatif kecil. Berikut analisa masalah dengan menggunakan arsitektur 10-10-10 pada perhitungan berikut :

Tahap inialisasi pada arsitektur 10-10-10 :

a. Tuliskan nilai input yang diberikan

1. Nilai Bobot dari Input ke Hidden Layer Pola 10 - 10-10 (Berikan nilai bobot (v) dari input ke lapisan tersembunyi dengan nilai acak).

2. Nilai Bobot dari Hidden Layer ke Output Pola 10-10-10 (Berikan nilai bobot (w) dari lapisan tersembunyi ke output dengan nilai acak).

3. Tahap iterasi :

a. Hitung Keluaran tiap node ( Y1 sampai Y10)

4. Hitung nilai error pada outpu layer dan error output pada hidden layer

1. Menghitung error pada output layer

2. Menghitung error pada hidden layer ( Y1 sampai YlO)

Modifikasi/hitung bobot baru

1. Menghitung bobot baru pada output layer ( $W_{1}$ sampai $W_{10}$ )

2. Menghitung bobot baru pada hidden layer $\left(V_{l}\right.$ Sampai $\left.V_{10}\right)$

5. Hasil training data penelitian diatas, maka dapat dihasilkan nilai bobot baru pada output layer dengan pola 10-10-10 .

6. Hasil Bobot Baru Pada Output Layer Pola 10-10-10

7. Hasil Bobot Baru Pada Hidden Layer Pola 10-10-10 
Data latih menghasilkan korelasi hasil Jaringan Syaraf terhadap perkiraan harga penjualan kopi yang belum maksimal. Disebabkan proses iterasi tidak mencapai error yang ditargetkan, Dari perkiraan analisa dengan pola 10-10-10 diperoleh hasil tidak maksimal, hal ini dikarenakan korelasi hasil Jaringan Syaraf Tiruan masih dalam iterasi pertama dan untuk maksimal target iterasi akan diuji menggunakan aplikasi Matlab R2013a.

Dalam melakukan pelatihan dan menentukan parameter jaringan maka dilakukan terlebih dahulu membentuk pola untuk identifikasi berdasarkan harga kopi pada tahun 2014 sampai dengan 2019, dimana pola tersebut akan dikelompokkan berdasarkan per provinsi. Variabelvariabel yang digunakan dalam membangunan jaringan ini meliputi, iterasi (epochs), laju pembelajaran (learning rate), jumlah neuron pada setiap hidden layer, goal, epochs dan learning rate ditentukan dengan cara melihat Mean Square Error (MSE) saat pelatihan dilakukan, semakin kecil MSE semakin baik kerja dari Jaringan Syaraf Tiruan. Awal pelatihan ditetapkan parameter dengan arsitektur jaringan 10 masukan (input), dan 10 lapisan tersembunyi (hidden layer) dan 10 keluaran (output). Pemilihan bobot awal dan bias menghasilkan bobot awal inisialisasi rendah. Jumlah pola yang dibutuhkan mempengaruhi tingkat akurasi. Perubahan nilai bobot dilakukan berdasarkan pola pelatihan yang terjadi ditambah momentum. Penghitungan nilai bobot dan bias dilakukan secara random dengan jangkauan -0,5 sampai dengan $+0,5$ (Prasetyo, 2012).

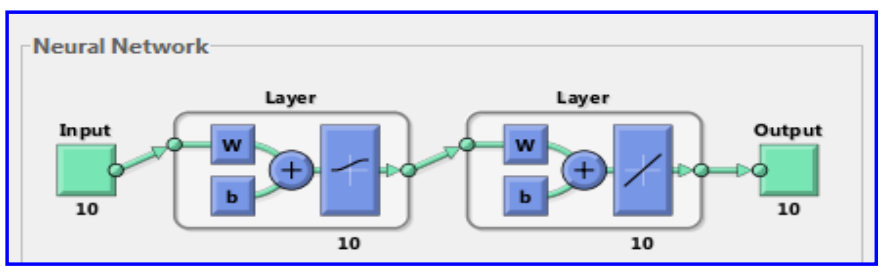

Gambar 2. Input 10 Hidden Layer Dan 10 Ouput

Pada pelatihan ini menggunakan nilai epoch antara 100 - 1000 dengan kenaikan tiap epoch 100. Parameter lain yang digunakan tetap dengan learning rate (lr) 0.1, target error (goal) 0.001, momentum $(\mathrm{mc}) 0.95$ dengan 10 neuron pada lapisan tersembunyi masing-masing memiliki 100 neuron.

Tabel 6. Hasil Pelatihan Penentuan Nilai Epoch

\begin{tabular}{|c|c|c|c|c|}
\hline No & Jumlah Epoch & Error Pelatihan & Akurasi (\%) & Jumlah Iterasi \\
\hline 1 & 100 & 0.0010898 & 99.9898 & 11 \\
\hline 2 & 200 & 0.0020509 & 99.9894 & 22 \\
\hline 3 & 300 & 0.0018499 & 99.9896 & 18 \\
\hline 4 & 400 & 0.001487 & 99.991 & 16 \\
\hline 5 & 500 & 0.002208 & 99.991 & 23 \\
\hline 6 & 600 & 0.0013326 & 99.9845 & 13 \\
\hline 7 & 700 & 0.0018451 & 99.991 & 21 \\
\hline 8 & 800 & 0.0015217 & 99.9878 & 14 \\
\hline 9 & 900 & 0.0015118 & 99.9881 & 21 \\
\hline 10 & 1000 & 0.0016772 & 99.9881 & 10 \\
\hline
\end{tabular}

Hasil pelatihan jaringan menunjukkan nilai epoch 100 memiliki nilai error pelatihan sebesar 0.0010898 dengan akurasi sebesar $99.9898 \%$ dan pembelajaran berhenti pada epoch 11 karena error pelatihan sudah dicapai dan sudah melampaui target error (goal), berdasarkan dari hasil pelatihan diatas maka parameter yang akan digunakan dalam penelitian adalah dengan epoch 100. Setelah melakukan penentuan nilai epoch, dilanjutkan dengan penentuan nilai learning rate terhadap kerja jaringan dengan tujuan untuk mendapatkan nilai laju pembelajaran yang optimal, kinerja learning rate terhadap jaringan ditentukan pada besar kecilnya MSE dan epoch selama 
pelatihan. Parameter yang digunakan pada pelatihan ini yaitu, target error (goal) $0.001, m c 0.5$, arsitektur jaringan sama dengan yang digunakan pada pelatihan sebelumnya, serta nilai epoch 100 sesuai hasil pelatihan terbaru.

Perhitungan feedforward (tahap propagasi maju), pada tahap ini tiap lapisan menerima sinyal masukan dari lapisan sebelumnya, diteruskan ke lapisan selanjutnya. Lapisan tersembunyi menerima sinyal masukan dari lapisan masukan, selanjutnya diteruskan ke lapisan keluaran. Lalu hitung semua keluaran dari lapisan tersembunyi $Z_{j}(j=1,2, \ldots, \mathrm{p})$ :

$Z_{-} n e t j=\left[v_{j o} \sum_{i=1}^{n} x_{i} v_{j i}\right]$

1. Mencari hitungan Propagasi Maju ( $Z \_n e t$ ) : Nilai 2,791513016 (nilai bias lapisan masukan ke lapisan tersembunyi) diambil dari Tabel. 4.13. Nilai Bias Lapisan Masukan ke Lapisan Tersembunyi pola $10-10-1$

2. Nilai 1 ( inputan masukan data awal setelah dinormalisasi)

3. Nilai 0,060918 (nilai Bobot Awal Lapisan Tersembunyi ke Lapisan Keluaran input masukan ke lapisan tersembunyi)

4. Tahapan propagasi mundur (Backpropagation), pada tahap ini nilai keluaran dari output layer dibandingkan dengan target output. Ketika nilai target belum terpenuhi maka akan dilakukan penyesuaian terhadap bobot dan bias, penyesuaian bobot dan bias diawali dengan perhitungan tingkat error :

$\delta_{k}=\left(t_{k}-y_{k}\right) y_{k}\left(1_{-} y_{k}\right)$

$\delta_{\mathrm{K}}=$ Tahapan Alur Mundur (Backpropagation)

$\mathrm{Tk}=$ Sinyal Bobot Dari Lapisan Tersembunyi Ke Lapisan Keluaran ; Yk = Hasil Nilai Keluaran Pada Lapisan Keluaran

5. Hitung faktor kesalahan $\delta$ pada lapisan tersembunyi berdasarkan error yang terdapat pada tiap-tiap unit lapisan tersembunyi $z_{j}(j=1,2, \ldots, p)$.

$$
\delta_{\text {net }(j)}=\sum_{k=1}^{m}\left(\delta_{k}, w_{k j}\right)
$$

6. Kemudian hitung nilai error $\delta$ diunit tersembunyi (hidden layer) dengan menggunakan persamaan:

$$
\delta_{k}=\delta_{\text {net } j} f^{\prime}\left(z_{-} \text {net } t_{j}\right)=\delta_{\text {net } j} * Z_{j} *\left(1-z_{j}\right)
$$

Hasil perhitungan perubahan nilai bobot dari lapisan masukan ke lapisan tersembunyi, Tabel 7.

\begin{tabular}{|c|c|c|c|c|c|c|c|c|c|c|}
\hline v1 & $-0,00185$ & $-0,00176$ & $-0,00185$ & $-0,00177$ & $-0,00185$ & $-0,00177$ & 0,001818993 & $-0,00185$ & $-0,00184$ & $-0,0018$ \\
\hline v2 & $\begin{array}{c}5,13 \mathrm{E}- \\
05\end{array}$ & $\begin{array}{c}4,87 \mathrm{E}- \\
05\end{array}$ & $\begin{array}{c}5,13 \mathrm{E}- \\
05\end{array}$ & $\begin{array}{c}4,92 \mathrm{E}- \\
05\end{array}$ & $\begin{array}{c}5,13 \mathrm{E}- \\
05\end{array}$ & $\begin{array}{c}4,91 \mathrm{E}- \\
05\end{array}$ & $5,04401 \mathrm{E}-05$ & $\begin{array}{c}5,13 \mathrm{E}- \\
05\end{array}$ & $5,1 \mathrm{E}-05$ & $\begin{array}{c}4,99 \mathrm{E}- \\
05\end{array}$ \\
\hline v3 & $-0,00028$ & $-0,00027$ & $-0,00028$ & $-0,00027$ & $-0,00028$ & $-0,00027$ & $\begin{array}{c}- \\
0,000275041 \\
\end{array}$ & $-0,00028$ & $-0,00028$ & $-0,00027$ \\
\hline v4 & $-0,00576$ & $-0,00547$ & $-0,00576$ & $-0,00552$ & $-0,00576$ & $-0,00551$ & $\begin{array}{c}- \\
0,005665504 \\
\end{array}$ & $-0,00576$ & $-0,00572$ & $-0,0056$ \\
\hline v5 & $-1 \mathrm{E}-04$ & $-9,5 \mathrm{E}-05$ & $-1 \mathrm{E}-04$ & $-9,6 \mathrm{E}-05$ & $-1 \mathrm{E}-04$ & $-9,6 \mathrm{E}-05$ & $\begin{array}{c}-9,82818 \mathrm{E}- \\
05\end{array}$ & $-1 \mathrm{E}-04$ & $-9,9 \mathrm{E}-05$ & $-9,7 \mathrm{E}-05$ \\
\hline v6 & $\begin{array}{c}1,26 \mathrm{E}- \\
05\end{array}$ & $\begin{array}{c}1,19 \mathrm{E}- \\
05\end{array}$ & $\begin{array}{c}1,26 \mathrm{E}- \\
05\end{array}$ & $\begin{array}{c}1,21 \mathrm{E}- \\
05\end{array}$ & $\begin{array}{c}1,26 \mathrm{E}- \\
05\end{array}$ & $1,2 \mathrm{E}-05$ & $1,23642 \mathrm{E}-05$ & $\begin{array}{c}1,26 \mathrm{E}- \\
05\end{array}$ & $\begin{array}{c}1,25 \mathrm{E}- \\
05 \\
\end{array}$ & $\begin{array}{c}1,22 \mathrm{E}- \\
05\end{array}$ \\
\hline v7 & $\begin{array}{c}0,00018 \\
7\end{array}$ & $\begin{array}{c}0,00017 \\
7 \\
\end{array}$ & $\begin{array}{c}0,00018 \\
7 \\
\end{array}$ & $\begin{array}{c}0,00017 \\
9\end{array}$ & $\begin{array}{c}0,00018 \\
7\end{array}$ & $\begin{array}{c}0,00017 \\
9\end{array}$ & 0,000183914 & $\begin{array}{c}0,00018 \\
7 \\
\end{array}$ & $\begin{array}{c}0,00018 \\
6 \\
\end{array}$ & $\begin{array}{c}0,00018 \\
2\end{array}$ \\
\hline v8 & $-2,1 \mathrm{E}-05$ & $-2 \mathrm{E}-05$ & $-2,1 \mathrm{E}-05$ & $-2 \mathrm{E}-05$ & $-2,1 \mathrm{E}-05$ & $-2 \mathrm{E}-05$ & $\begin{array}{c}-2,05969 \mathrm{E}- \\
05\end{array}$ & $-2,1 \mathrm{E}-05$ & $-2,1 \mathrm{E}-05$ & $-2 \mathrm{E}-05$ \\
\hline
\end{tabular}

Tabel 7. Perubahan Nilai Bobot dari Layer Input

eISSN: 2477-3255, pISSN: 2086-4884

https://doi.org/10.31849/digitalzone.v11i1.3880 
Hitung koreksi nilai bias dari ke lapisan tersembunyi (hidden layer), Tabel 8.

Tabel 8. Perubahan Nilai Bias Layer Tersembunyi

\begin{tabular}{|c|c|}
\hline Bias & Nilai bias $\left(\mathrm{v}_{\mathrm{j}}\right)$ \\
\hline 1 & 2,207479362 \\
\hline 2 & 5,527360604 \\
\hline 3 & $-7,207540997$ \\
\hline 4 & 5,547124856 \\
\hline 5 & $-4,79456762$ \\
\hline 6 & $-0,590331129$ \\
\hline 7 & $-2,366767941$ \\
\hline 8 & 6,657828092 \\
\hline 9 & $-0,783781972$ \\
\hline 10 & $-2,993030454$ \\
\hline
\end{tabular}

Dari tahapan-tahapan yang dilakukan menggunakan metode Backpropagation, diperoleh nilai keluaran berupa hasil prediksi. Hasil prediksi dari contoh perhitungan manual menggunakan metode Backpropagation berupa nilai output yang dicapai setelah pelatihan yang kemudian dibandingkan dengan target yang akan dicapai. Dari perbandingan nilai output dan target didapat nilai error yang terjadi selama pelatihan JST. Dari tahapan-tahapan yang dilakukan menggunakan metode Backpropagation, diperoleh nilai keluaran berupa hasil prediksi harga kopi Arabika dan Robusta. Hasil prediksi dari contoh perhitungan manual menggunakan metode Backpropagation berupa nilai output yang dicapai setelah pelatihan yang kemudian dibandingkan dengan target yang akan dicapai. Dari perbandingan nilai output dan target didapat nilai error yang terjadi selama pelatihan JST seperti dimuat pada tabel 9 menghasilkan akurasi prediksi sebesar 99.9887 dengan error MSE 0,16644

Tabel 9. Hasil Prediksi Jaringan Saraf Tiruan

\begin{tabular}{|c|c|c|c|c|c|c|}
\hline \multirow{3}{*}{ Tahun 2019 } & Bulan & Input & Output & $\begin{array}{c}\text { Hasil } \\
\text { Prediksi }\end{array}$ & Harga Aktual & Akurasi (\%) \\
\hline \multirow{5}{*}{ Jan - Des } & 1 & 1 & 1 & 73744 & 74205 & 99.41918 \\
\cline { 2 - 7 } & 2 & 0.949527 & 0.977105 & 73611 & 73892 & 99.61972 \\
\cline { 2 - 7 } & 3 & 1 & 1 & 77545 & 77981 & 99.44089 \\
\cline { 2 - 7 } & 4 & 0.959242 & 0.970107 & 72734 & 72850 & 99.84077 \\
\cline { 2 - 7 } & 6 & 1 & 1 & 74131 & 74916 & 98.52216 \\
\cline { 2 - 7 } & 7 & 0.957425 & 0.956934 & 74145 & 73422 & 100.9847 \\
\cline { 2 - 7 } & 8 & 0.984 & 0.985836 & 73886 & 74152 & 99.64128 \\
\hline & 9 & 0.993978 & 0.996555 & 75728 & 74810 & 100.8178 \\
\cline { 2 - 7 } & 10 & 0.972701 & 1 & 74628 & 78307 & 94.87913 \\
\hline
\end{tabular}

Dari hasil perhitungan manual yang dilakukan pada 10 sampel terdapat selisih harga pada kisaran -1437 rupiah hingga 7299 rupiah. Selisih harga ini relatif baik sehingga memberikan indikasi bahwa metode Backpropagation dengan arsitektur $10-10-10$ mampu melakukan prediksi harga kopi dengan baik. Hasil Akurasi 99.9530 didapat dari Hasil Prediksi bernilai 74628 dibagi dengan Harga Aktual bernilai 78307 dikali 100 maka diperoleh hasil Akurasi 94.87913. Akurasi $(\%)=94.87913$. Hasil rancangan Form Neural Network Training (Gambar 3) merupakan form untuk menampilkan hasil tampilan Home yang setelah perintah hitung akurasi telah diproses. Hasil pengolahan prediksi harga kopi dengan epoch 1000 atau 2000 akan menghasilkan perfomance iterasi yang sama, Form Neural Network Training (Gambar 3b) merupakan form untuk menampilkan hasil tampilan Home yang setelah perintah hitung akurasi telah diproses. Hasil pengolahan prediksi harga kopi dengan epoch 1000 atau 2000 akan menghasilkan perfomance iterasi yang sama. 

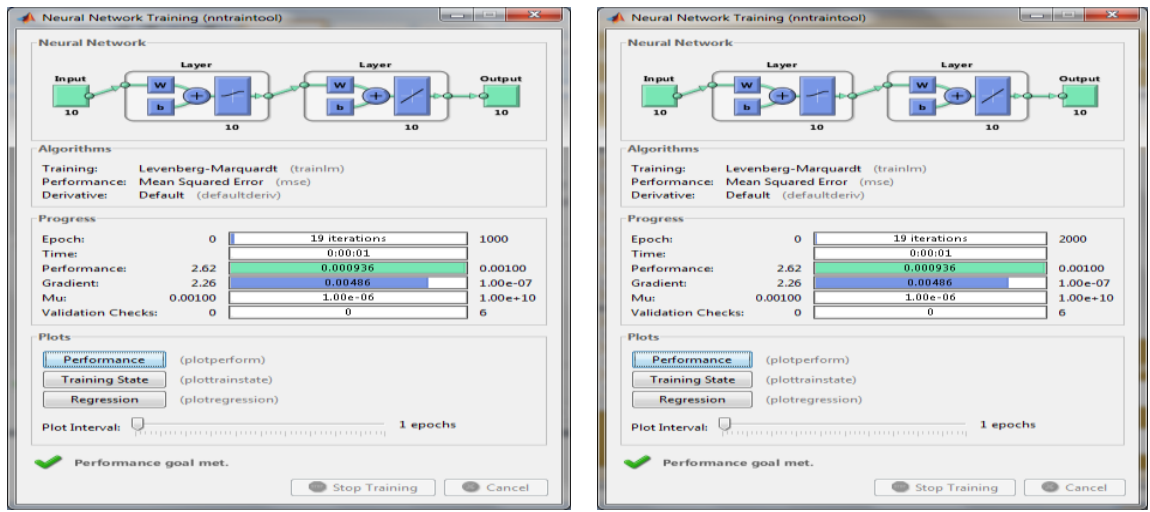

Gambar 3. Hasil Rancangan Neural Network Training

Form Proses Hitungan prediksi harga kopi merupakan form yang menampilkan proses perhitungan untuk mencapai akurasi, error MSE dan hasil Uji Data Prediksi. Untuk hasil prediksi harga lebih jelasnya dapat dilihat pada Gambar 4 dengan Gambar arsitektur jaringan 10 $-10-10$.

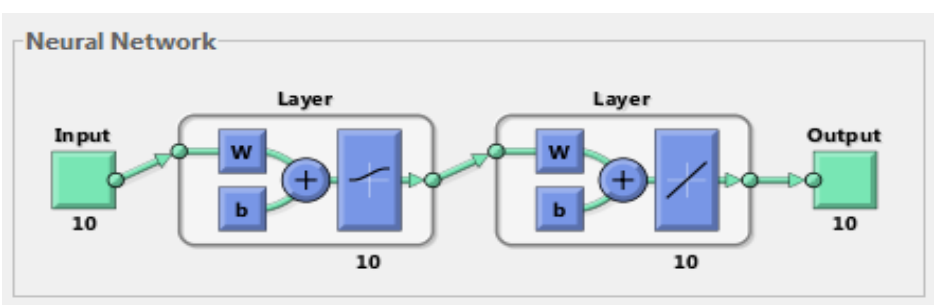

Gambar 4. Form Proses Hitungan Prediksi Harga Kopi

Berdasarkan pengujian sistem Matlab R2013a dalam memprediksi harga kopi maka hasil prediksi harga kopi dari harga aktual 74205 ke hasil harga prediksi 73668 dengan akurasi 99.9928, harga aktual 73892 ke harga prediksi 73175 dengan akurasi 99.9903, harga aktual 77981 ke hasil prediksi 77481 dengan akurasi 99.9936, Tabel 10 dan Tabel 11.

Tabel 10. Hasil Prediksi Harga Kopi

\begin{tabular}{|c|l|c|c|c|c|c|c|c|c|c|}
\hline No. & $\begin{array}{c}\text { Nama } \\
\text { Provinsi }\end{array}$ & $\begin{array}{c}\text { Jumlah } \\
\text { Data Uji } \\
(\text { Neuron) }\end{array}$ & $\begin{array}{c}\text { Data } \\
\text { Real } \\
(\mathrm{a})\end{array}$ & $\begin{array}{c}\text { Prediksi } \\
(\mathrm{b})\end{array}$ & $\begin{array}{c}\text { Prediksi } \\
\left(\mathrm{b}_{\mathrm{n}}\right)\end{array}$ & $\begin{array}{c}\text { Akurasi } \\
(\mathrm{b})\end{array}$ & $\begin{array}{c}\text { Akurasi } \\
\left(\mathrm{b}_{\mathrm{n}}\right)\end{array}$ & $\begin{array}{c}\text { Akurasi } \\
\text { Terting } \\
\mathrm{i}\end{array}$ & $\begin{array}{c}\text { Pemetaan } \\
\text { Kopi } \\
\text { Arabika }\end{array}$ & $\begin{array}{c}\text { Pemetaan } \\
\text { Kopi } \\
\text { Robusta }\end{array}$ \\
\hline 1 & $\begin{array}{l}\text { Sumatera } \\
\text { Utara }\end{array}$ & 10 & 74205 & 73774 & 74487 & 99.9942 & 99.9962 & $\mathrm{~b}_{\mathrm{n}}$ & 73774 & 74145 \\
\hline 2 & Aceh & 10 & 73892 & 73611 & 73952 & 99.9962 & 99.9992 & $\mathrm{~b}_{\mathrm{n}}$ & 73611 & 73886 \\
\hline 3 & $\begin{array}{l}\text { Sulawesi } \\
\text { Selatan }\end{array}$ & 10 & 77981 & 77545 & 78108 & 99.9944 & 99.9984 & $\mathrm{~b}_{\mathrm{n}}$ & 77545 & 81612 \\
\hline 4 & $\begin{array}{l}\text { Sumatera } \\
\text { Barat }\end{array}$ & 10 & 72981 & 72734 & 73234 & 99.9964 & 99.9947 & $\mathrm{~b}$ & 72734 & 75728 \\
\hline 5 & NTT & 10 & 74916 & 74131 & 75493 & 99.9895 & 99.9923 & $\mathrm{~b}_{\mathrm{n}}$ & 74131 & 74297 \\
\hline 6 & $\begin{array}{l}\text { Sumatera } \\
\text { Utara }\end{array}$ & 10 & 73422 & 74145 & 74666 & 99.9902 & 99.9831 & $\mathrm{~b}$ & - \\
\hline 7 & Aceh & 10 & 74152 & 73886 & 74354 & 99.9964 & 99.9973 & $\mathrm{~b}_{\mathrm{n}}$ & - & - \\
\hline 8 & $\begin{array}{l}\text { Sulawesi } \\
\text { Selatan }\end{array}$ & 10 & 80950 & 81612 & 81661 & 99.9918 & 99.9912 & $\mathrm{~b}$ & - \\
\hline 9 & $\begin{array}{l}\text { Sumatera } \\
\text { Barat }\end{array}$ & 10 & 74810 & 75728 & 75118 & 99.9877 & 99.9959 & $\mathrm{~b}_{\mathrm{n}}$ & - \\
\hline 10 & NTT & 10 & 78307 & 74297 & 74108 & 99.9488 & 99.9464 & $\mathrm{~b}$ & - \\
\hline
\end{tabular}


Tabel . 11. Hasil Pemetaan Harga Kopi Arabika dan Kopi Robusta

\begin{tabular}{|c|l|c|c|c|c|}
\hline \multirow{2}{*}{ No. } & \multirow{2}{*}{ Provinsi } & \multicolumn{2}{|c|}{ Jeni Kopi (Harga Kopi Real) } & \multicolumn{2}{c|}{$\begin{array}{c}\text { Pemetaan Prediksi } \\
\text { Harga Kopi 2019 (Desember) }\end{array}$} \\
\cline { 3 - 6 } & & Arabika & Robusta & Arabika & Robusta \\
\hline 1 & Sumatera Utara & 74205 & 73422 & 73774 & 74145 \\
\hline 2 & Aceh & 73892 & 74152 & 73611 & 73886 \\
\hline 3 & Sulawesi Selatan & 77981 & 80950 & 77545 & 81612 \\
\hline 4 & Sumatera Barat & 72981 & 74810 & 72734 & 75728 \\
\hline
\end{tabular}

\section{Kesimpulan}

Dari penelitian algoritma Backpropagation dalam memprediksi harga komoditi terhadap pemetaan karakteristik konsumen pada produk kopi lokal nasional yang telah dianalisa dan diimplementasikan menghasilkan beberapa kesimpulan antara lain analisa untuk algoritma Backpropagation dalam memprediksi harga Kopi Arabika dan Robusta mampu memberikan hasil akurasi 99.9988 dengan error MSE 0,0015644 dengan menggunakan data bersifat time series. Hasil analisa dengan algoritma Backpropagation yang telah dibangun maka tercapailah hasil rancangan algoritma Backpropagation dengan menghasilkan pemetaan harga kopi per provinsi, dengan arsitektur jaringan inputan masukan 10 dan neuron 10 serta lapisan tersembunyi 10, dengan bobot sudah ditetapkan menghasilkan akurasi $99.9936 \%$. Hasil prediksi harga kopi dari harga aktual 74205 ke hasil harga prediksi 73668 dengan akurasi 99.9928, harga aktual 73892 ke harga prediksi 73175 dengan akurasi 99.9903, harga aktual 77981 ke hasil prediksi 77481.

\section{Daftar Pustaka}

[1] I. S. Purba, A. Wanto, Prediksi Jumlah Nilai Impor Sumatera Utara Menurut Negara Asal Menggunakan Algoritma Backpropagation, Techno.COM, Vol. 17, No. 3, hal: :302-311, 2018.

[2] D. Mutiasari, V. S. Paramita, Pengaruh Profitabilitas Terhadap Harga Saham Dengan Struktur Modal Sebagai Variabel Intervening Pada Sektor Property \& Real Estate Yang Terdaftar Di Bursa Efek Indonesia Periode 2012 - 2016, Prosiding Working Papers Series In Management, hal 144-159, 2016.

[3] A. P. Windarto, M. R. Lubis, Solikhun, Model Arsitektur Neural Network Dengan Backpropogation Pada Prediksi Total Laba Rugi Komprehensif Bank Umum Konvensional, Kumpulan jurnaL Ilmu Komputer (KLIK), Volume 05, No.02, hal 146$158,2018$.

[4] A. S. RM. Sinaga, R. N. Zendrato, Optimasi Penugasan Pegawai Menggunakan Metode Hungarian, Journal of Innovation Information Technology and Application (JINITA), Volume 1, Nomor 01, Pages 16-24, 2019.

[5] Yalidhan, M. Dedek, Implementasi Algoritma Backpropagation Untuk Memprediksi Kelulusan Mahasiswa, Klik- Kumpulan Jurnal Ilmu Komputer, Vol 5, No 2, 2018.

[6] Hindarto, I. Anshory, A. E. Yanti, Klasifikasi Sinyal Jantung Menggunakan Jaringan Syaraf Backpropagation Classification of Heart Signals Using Backpropagation Neural Network, Jurnal Saintek, Vol. 13. No. 2, hal: : 99-102, 2016.

[7] O. Vermesan, M. Eisenhauer, H. Sunmaeker, P. Guillemin, M. Serrano, E. Z. Tragos, J. Valino, A. van der Wees, A. Gluhak, and R. Bahr, Internet of things cognitive transformation technology research trends and applications, Cognitive Hyperconnected Digital Transformation; Vermesan, O., Bacquet, J., Eds, pp. 17-95, 2017.

[8] W. Shi, J. Cao, Q. Zhang, Y. Li, and L. Xu, Edge computing: Vision and challenges, IEEE Internet of Things Journal, vol. 3, no. 5, pp. 637-646, 2016. 
[9] J. Secco, M. Poggio, and F. Corinto, Supervised Neural Networks With Memristor Binary Synapses, International Journal of Circuit Theory and Applications, vol. 46, no. 1, pp. 221-233, 2018.

[10] C. D. Suhendra, R. Wardoyo, Penentuan Arsitektur Jaringan Syaraf Tiruan Backpropagation (Bobot Awal dan Bias Awal) Menggunakan Algoritma Genetika IJCCS, Vol.9, No.1, pp. 77-88, 2015.

[11] H. Y. Sari, "Optimasi Conjugate Gradient Pada Algoritma Backpropagation Neural Network Untuk Prediksi Kurs Time Series," Jurnal Gema Aktualita, 2016, vol. 5, no. 1, pp. 86-90, 2016.

[12] S. Setti, A. Wanto, Analysis of Backpropagation Algorithm in Predicting the Most Number of Internet Users in the World, OIN (Jurnal Online Informatika), Volume 3 No. 2 hal: $110-115,2018$.

[13] A. F. Achmalia, Walid, Sugiman, Peramalan Penjualan Semen Menggunakan Backpropagation Neural Network Dan Recurrent Neural Network, UNNES Journal of Mathematics, 8(1) hal: 92-105, 2019.

[14] P. Marpaung, A. Sitio, A. Sindar, Optimization of Sugar Salt Fat in the Human Body Using Genetic Algorithm, SinkrOn : Jurnal dan Penelitian Teknik Informatika, Volume 4, Number 2, hal: 85-91, 2020.

[15] N. Nurmila, A. Sugiharto, E. A. Sarwoko, Algoritma Back Propagation Neural Network Untuk Pengenalan Pola Karakter Huruf Jawa, Jurnal Masyarakat Informatika, Volume 1, Nomor 1 hal: 1-10, 2017.

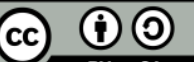

Digital Zone: Jurnal Teknologi Informasi dan Komunikasi is licensed under a Creative Commons Attribution International (CC BY-SA 4.0) 